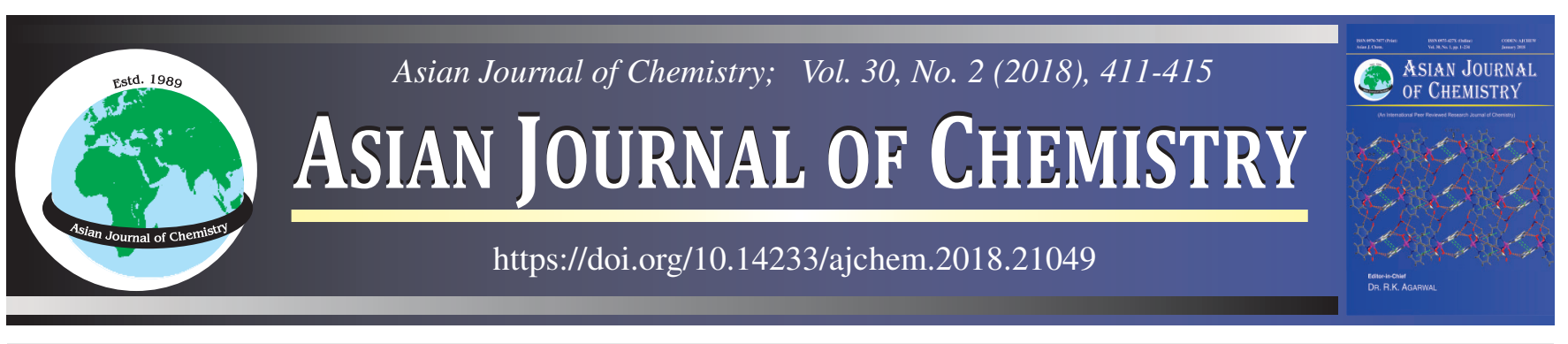

\title{
Synthesis, Characterization and in vitro Cytotoxicity Studies of Pentadentate Ligand and its Copper(II) Complexes
}

\author{
UMAPATHy ChOKKanATHAN and KanNAPPAN GeEtha*
}

PG \& Research Department of Chemistry, Muthurangam Government Arts College, Vellore-632 002, India

*Corresponding author: E-mail: senthil_geetha@rediffmail.com

A pentadentate ligand was synthesized by reaction of 4-t-butyl-2,6-bis(chloromethyl)phenol and isonicotinic hydrazide. The ligand was characterized by UV-visible, FT-IR, ${ }^{1} \mathrm{H}$ NMR, ${ }^{13} \mathrm{C}$ NMR and mass spectrascopic techniques. The above ligand was coordinated with various copper precursors to form corresponding copper(II) complexes. The complexes were characterized by UV-visible, FT-IR, molar conductivity and cyclic voltammetry. The in vitro cytotoxicity of the ligand and its copper complexes were studied against Ehrlich ascites carcinoma (EAC) cells.

Keywords: Isonicotinic hydrazide, Pentadentate ligand, Copper(II) complexes, in vitro cytotoxicity, Ehrlich ascites carcinoma cells.

\section{INTRODUCTION}

Transition metals are significant in living organisms to provide appropriate concentrations of metals for use in metalloproteins or cofactors. The redox properties of the metals are important in many of the reactions. Copper and iron proteins participate in many of the biological reactions like binding of dioxygen, e.g., hemocyanin $(\mathrm{Cu})$, hemerythrin $(\mathrm{Fe})$ and hemoglobin $(\mathrm{Fe})[1]$, activation of dioxygen in the synthesis of the hormone epinephrine, e.g., dopamine hydroxylase $(\mathrm{Cu})$, tyrosinases $(\mathrm{Cu})$ and catechol dioxygenases $(\mathrm{Fe})$ [2,3] electron transfer, e.g., plastocyanins $(\mathrm{Cu})$, ferredoxins and c-type cytochromes (Fe) [4] dismutation of superoxide by $\mathrm{Cu}$ or $\mathrm{Fe}$ as the redox-active metal (superoxide dismutases) [5].

Platinum and ruthenium are explored as potential anticancer agents. However, there is an emerging curiosity in the synthesis of low-cost first-row metal coordination compounds as efficient DNA binders with potential cytotoxic activity. Transition metal complexes exhibit a well-defined coordination geometries and distinct electrochemical or photophysical properties, thereby increasing the functionality of the binding agent. Redox-active metals generally form reactive oxygen species (ROS) and this ROS can be used to induce DNA cleavage [6-8]. The more donor atoms by which a molecule is bound to a metal ion, the stronger will be the assembly. A ligand of such kind was synthesized using 4-t-butyl-2,6bis(chloromethyl)phenol and isonicotinic hydrazide which was reacted with copper(II) precursors to form copper(II) complexes.

\section{EXPERIMENTAL}

All the chemicals and solvents were purchased from SDFine Chemicals. UV-visible spectra were recorded using Systronics spectrophotometer operating in the range of 200-800 nm. FT-IR spectra were obtained in Shimadzu IR-Affinity-I spectrometer and sample pellets were prepared using KBr. ${ }^{1} \mathrm{H}$ NMR and ${ }^{13} \mathrm{C}$ NMR spectrum of ligand was recorded from Bruker 400 $\mathrm{MHz}$ spectrometer. Conductance of complexes was recorded using Elico conductometer. Cyclic voltammetry was done in $\mathrm{HCH}$ Instruments.

Synthesis of ligand: 4- $t$-Butyl-2,6-bis(chloromethyl)phenol was treated with isonicotinic hydrazide in ethanol in 1:2 ratio $[9,10]$. A yellow solid was obtained, filtered and recrystallized in ethanol (Scheme-I).

Synthesis of copper precursors: Cinnamic acid was dissolved in hot water by heating at above room temperature. To this sodium hydroxide was added and stirred in a magnetic stirrer. A solution of copper sulphate $\left(\mathrm{CuSO}_{4} \cdot 5 \mathrm{H}_{2} \mathrm{O}\right)$ in water was slowly added to the mixture in 1:2 ratio [11-13]. A light blue solid obtained, filtered and washed with water (SchemeII).

Synthesis of copper complexes: The above ligand was dissolved in ethanol. Sodium hydroxide was added and stirred for few minutes. A solution of copper precursors in ethanol was slowly added and sodium perchlorate was added in 1:1:1:2 and continued stirring for $5 \mathrm{~h}$ [14-16]. A dark green solid was obtained and filtered (Scheme-III). Similarly, copper succinate (C6P2) and copper crotonate (C6P3) complexes were synthesized. 
4-t-Butyl-2,6-bis(chloromethyl)phenol<smiles>CC(C)(C)c1cc(CCl)c(O)c(CCl)c1</smiles><smiles>NNC(=O)c1ccncc1</smiles>

Isonicotinic hydrazide

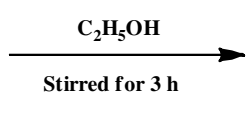

Scheme-I: Synthesis of ligand
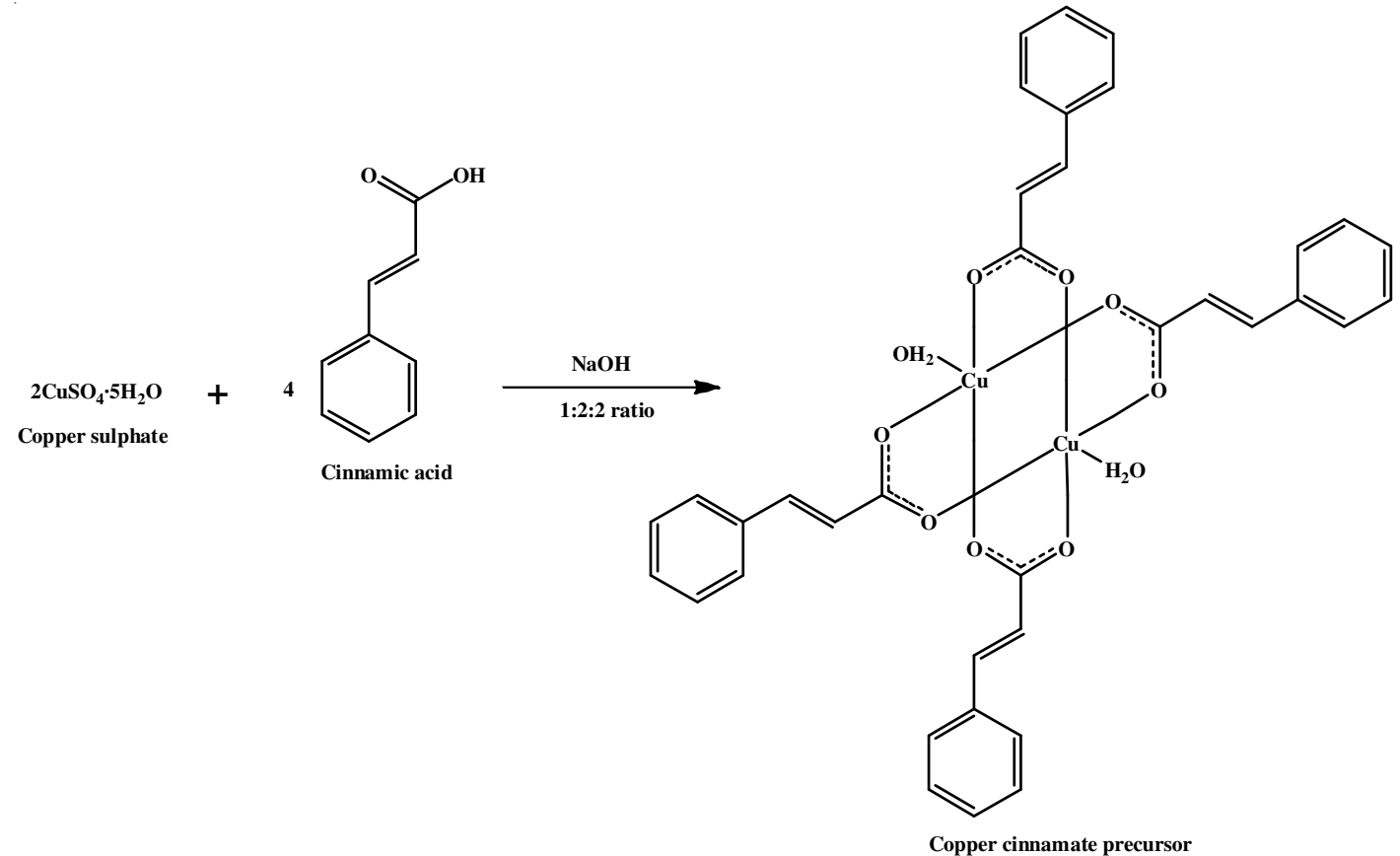

Scheme-II: Synthesis of copper precursor

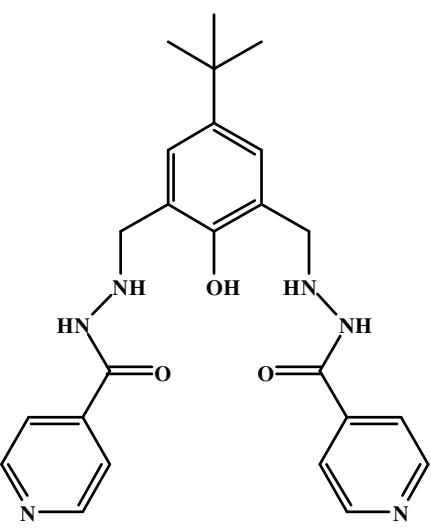

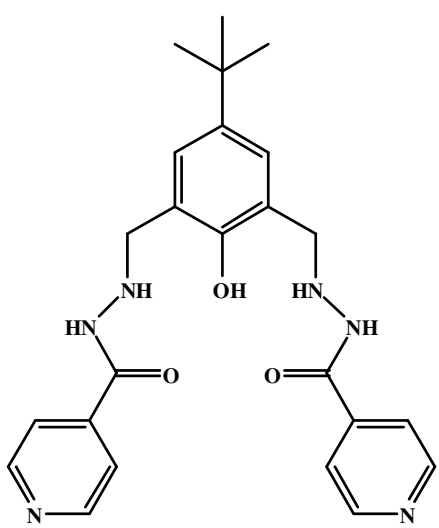

Copper cinnamate precurso

$\mathrm{NaOH} / \mathrm{NaClO}_{4}$

1:1:1:2 ratio

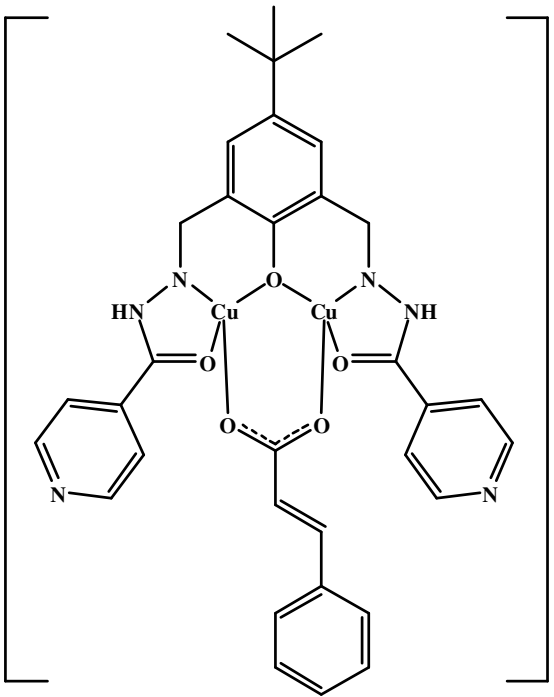

Scheme-III: Synthesis of copper complex (C6P1) 
in vitro Cytotoxicity study: The ligand and its $\mathrm{Cu}(\mathrm{II})$ complexes were studied for short term in vitro cytotoxicity using Ehrlich ascites carcinoma (EAC) cells. The tumor cells aspirated from the peritonial cavity of tumor bearing mice were washed thrice with phosphate buffered saline. Cell viability was determined by trypan blue exclusion method. Viable cell suspension $\left(1 \times 10^{6}\right.$ cells in $\left.0.1 \mathrm{~mL}\right)$ was added to tube containing various concentrations of the test compound and the volume was made up to $1 \mathrm{~mL}$ using phosphate buffered saline (PBS) [17-20]. Control tube contains only cell suspension. These assay mixture were incubated for $3 \mathrm{~h}$ at $37^{\circ} \mathrm{C}$. Further cell suspension was mixed with $0.1 \mathrm{~mL}$ of $1 \%$ trypan blue and kept for 2 to $3 \mathrm{~min}$ and loaded on hemocytometer. Dead cells take up the blue colour of trypan blue while live cells do not take up the dye. The number of stained and unstained cells was counted separately [21,22].

\section{RESULTS AND DISCUSSION}

A pentadentate ligand (L6) was characterized by UVvisible, FT-IR, ${ }^{1} \mathrm{H}$ NMR, ${ }^{13} \mathrm{C}$ NMR spectral studies. The UVvisible spectrum of the ligand (Fig. 1) shows $\pi-\pi *$ transition at $291 \mathrm{~nm}, \mathrm{n}-\pi^{*}$ transition at $329 \mathrm{~nm}$ and charge transfer at $387 \mathrm{~nm}$. The FT-IR spectrum (Fig. 2) shows OH stretching at $3329 \mathrm{~cm}^{-1}, \mathrm{NH}$ stretching at $3247 \mathrm{~cm}^{-1}$, aromatic $\mathrm{CH}$ stretching at $2958 \mathrm{~cm}^{-1}, \mathrm{C}=\mathrm{O}$ stretching at $1651 \mathrm{~cm}^{-1}, \mathrm{CO}$ stretching at $1207 \mathrm{~cm}^{-1}$. The ${ }^{1} \mathrm{H}$ NMR spectrum (Fig. 3) shows aromatic protons adjacent to nitrogen at 9.006 , aromatic protons away from nitrogen at 7.804, methylene proton at $4.575 .{ }^{13} \mathrm{C} \mathrm{NMR}$ spectrum (Fig. 4) shows hydroxyl carbon at 147.3, $t$-butyl carbon at 31.34, carbonyl carbon at 164.42, aromatic carbon adjacent to nitrogen at 150.27 , aromatic protons away from nitrogen at 121.91. The mass spectrum (Fig. 5) shows peaks at $m / e$ values $448,269,161$, etc., shows the presence of molecular ion peak and fragmented ion peaks $[23,24]$.

The copper complexes were characterized by UV-visible, FT-IR spectral studies, conductivity measurements and cyclic voltammetry.

UV-visible: The UV-visible spectra of the complexes were recorded in DMSO solution in the wavelength range 200-800 $\mathrm{nm}$. The band at $291 \mathrm{~nm}$ is due to $\pi-\pi^{*}$ transition of the benzene

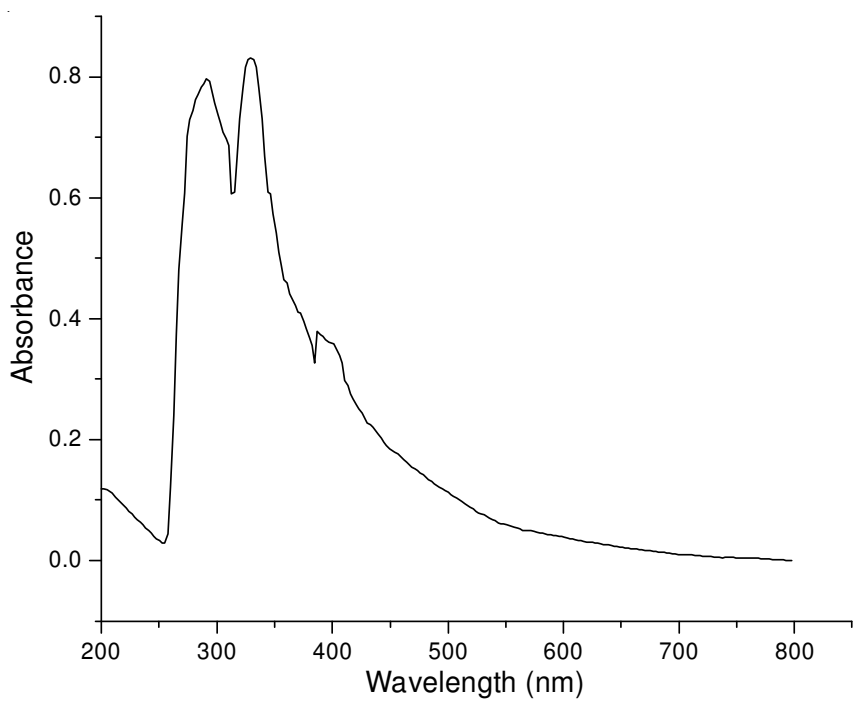

Fig. 1. UV-visible spectrum of ligand

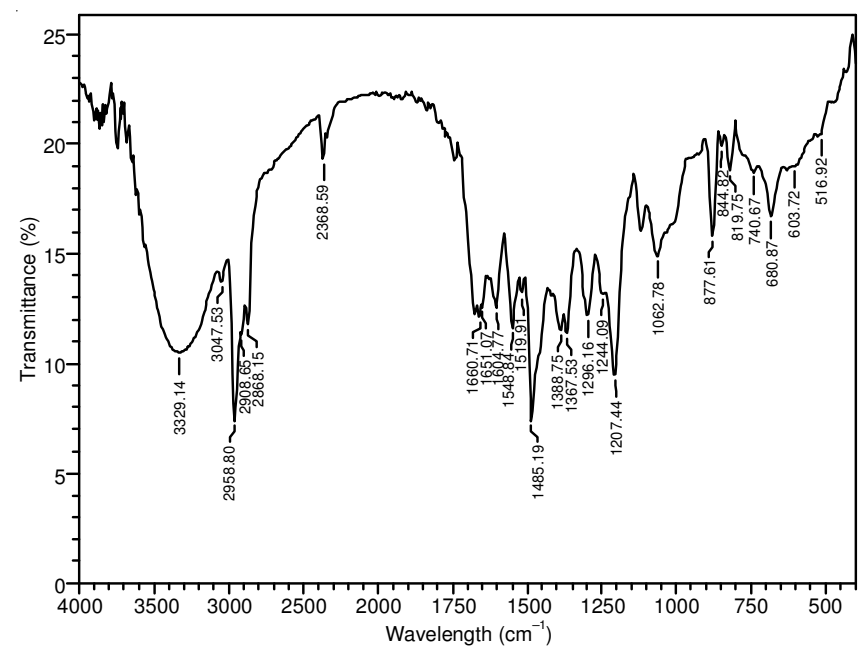

Fig. 2. FT-IR spectrum of ligand

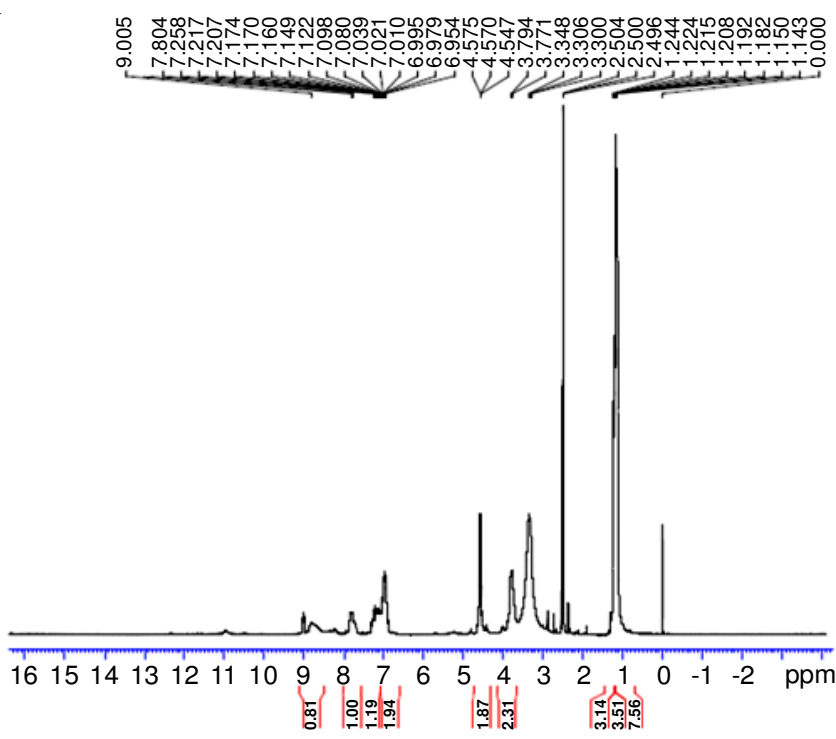

Fig. $3 .{ }^{1} \mathrm{H}$ NMR spectrum of ligand
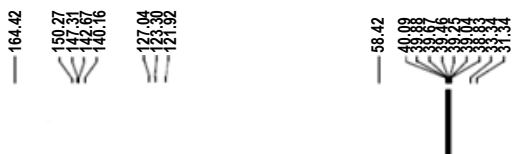

$21020019018017016015014013012011010090 \quad 8070 \quad 60 \quad 5040 \quad 302010 \quad 0 \quad$ ppm Fig. $4 .{ }^{13} \mathrm{C}$ NMR spectrum of ligand

ring present in the ligand and it was shifted to higher wavelength (red shift) upon complexation and the band was observed around $300 \mathrm{~nm}$ for complexes. Similarly, the band 


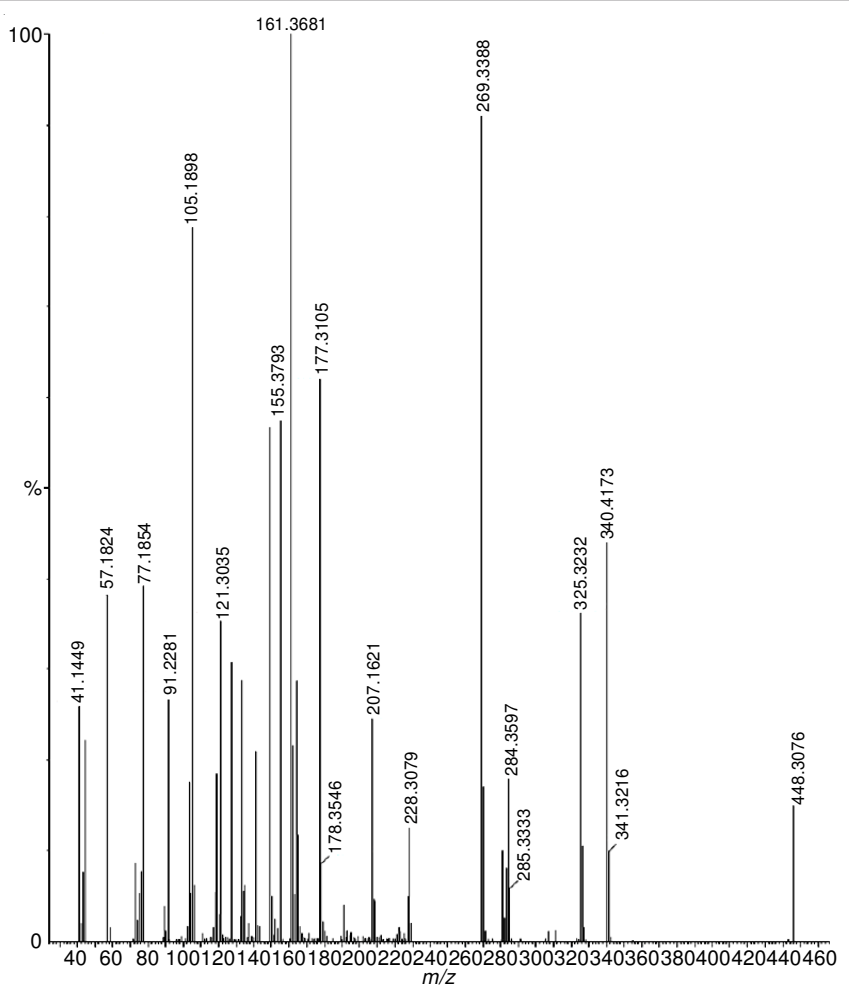

Fig. 5. Mass spectrum of ligand

at $329 \mathrm{~nm}$ is due to $\mathrm{n}-\pi^{*}$ transition of nitrogen in the ligand and it was shifted to higher wavelength (red shift) upon complexation and the band was observed around $350 \mathrm{~nm}$ for complexes (Fig. 6). The band around $580 \mathrm{~nm}$ is due to $d$ - $d$ transition (Table-1) [25].

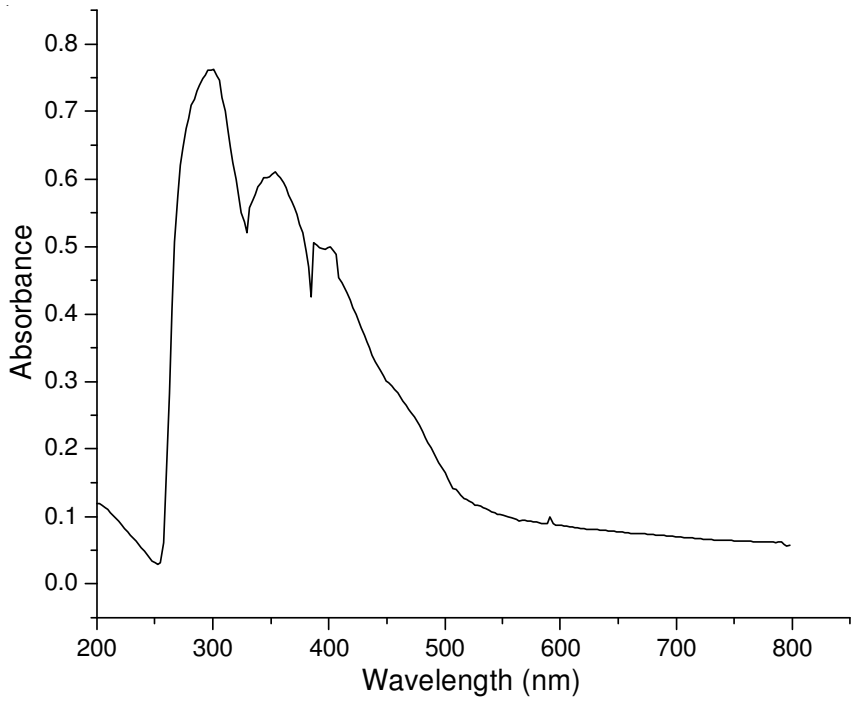

Fig. 6. UV-visible spectrum of complex (C6P1)

TABLE-1

UV-VISIBLE SPECTRAL DATA OF LIGAND AND COMPLEXES

\begin{tabular}{ccccc}
\hline \multirow{2}{*}{$\begin{array}{c}\text { Sample } \\
\text { code }\end{array}$} & $\begin{array}{c}\boldsymbol{\pi}_{-} \pi^{*} \\
\text { transition }\end{array}$ & $\begin{array}{c}\mathrm{n}-\pi^{*} \\
\text { transition }\end{array}$ & $\begin{array}{c}\text { Charge } \\
\text { transfer }\end{array}$ & $\begin{array}{c}d-d \\
\text { Transition }\end{array}$ \\
\cline { 2 - 5 } L6 & 291 & 329 & 387 & - \\
C6P1 & 296 & 358 & 399 & 591 \\
C6P2 & 298 & 346 & 401 & 567 \\
C6P3 & 300 & 348 & 401 & 584 \\
\hline
\end{tabular}

FT-IR spectroscopy: The FT-IR spectrum (Fig. 7) shows $\mathrm{OH}$ stretching around $3410 \mathrm{~cm}^{-1}$, NH stretching around 3310 $\mathrm{cm}^{-1}, \mathrm{CH}$ stretching around $2925 \mathrm{~cm}^{-1}$, OCO stretching around $1260 \mathrm{~cm}^{-1}, \mathrm{M}-\mathrm{N}$ stretching around $550 \mathrm{~cm}^{-1}$, M-O stretching around $450 \mathrm{~cm}^{-1}$. The other key bands of copper complexes are given in Table- 2 .

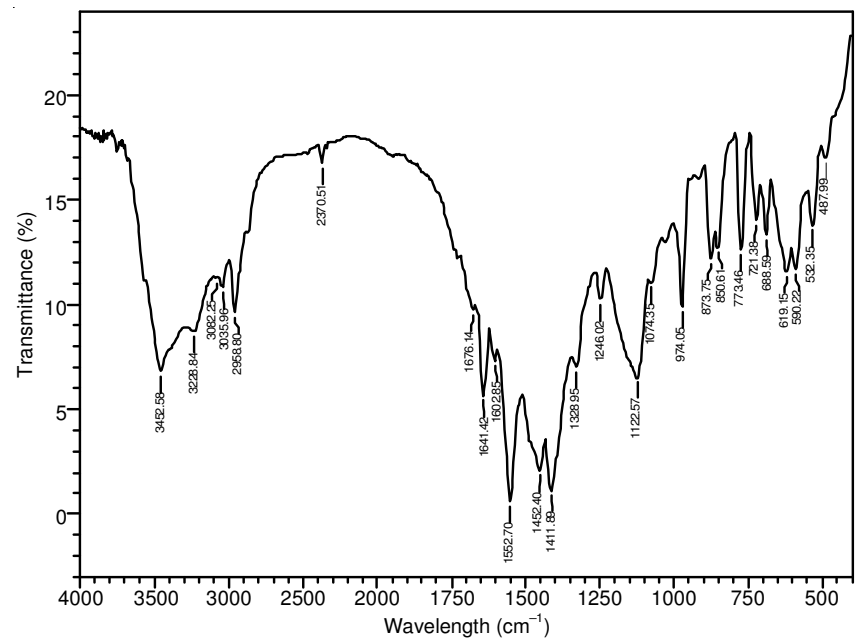

Fig. 7. FT-IR spectrum of complex C6P1

TABLE-2

FT-IR SPECTRAL DATA OF LIGAND AND COMPLEXES

\begin{tabular}{cccccccc}
\hline \multirow{2}{*}{$\begin{array}{c}\text { Sample } \\
\text { code }\end{array}$} & $\mathrm{OH}$ & $\mathrm{NH}$ & $\mathrm{Ar}-\mathrm{CH}$ & $\mathrm{C}=\mathrm{O}$ & $\mathrm{ClO}_{4}^{-}$ & $\mathrm{M}-\mathrm{N}$ & $\mathrm{M}-\mathrm{O}$ \\
\cline { 2 - 8 } & $\mathrm{O}$ Key infrared bands $\left(\mathrm{cm}^{-1}\right)$ \\
$\mathrm{L} 6$ & 3329 & 3247 & 2958 & 1651 & - & - & - \\
$\mathrm{C} 6 \mathrm{P} 1$ & 3452 & 3228 & 2958 & 1641 & 1122 & 773 & 532 \\
$\mathrm{C} 6 \mathrm{P} 2$ & 3444 & 3239 & 2960 & 1624 & 1118 & 808 & 534 \\
C6P3 & 3436 & 3243 & 2939 & 1589 & 1112 & 808 & 570 \\
\hline
\end{tabular}

Conductance measurements: The molar conductance of the complexes were recorded in dimethyl formamide (DMF). The molar conductance values shows that complexes are 1:2 electrolyte in nature (Table-3).

\begin{tabular}{cc} 
TABLE-3 \\
MOLAR CONDUCTANCE VALUES OF THE COMPLEXES \\
\hline Sample code & Molar conductance $\left({\left.\mathrm{Mho} \mathrm{cm}^{2} \mathrm{~mol}^{-1}\right)}^{\text {C6P1 }} 124\right.$ \\
C6P2 & 137 \\
C6P3 & 131 \\
\hline
\end{tabular}

Cyclic voltammetry: The cyclic voltammetry (Fig. 8) reveals that all the complexes exhibit a one electron transfer and the complexes are quasi reversible (Table-4). The electron movement is sluggish.

in vitro Cytotoxicity study: The copper complexes showed the significant increase in activity against Ehrlich ascites carcinoma (EAC) cell (Table-5) when compared to the

TABLE-4

CYCLIC VOLTAMMETRIC DATA OF THE COMPLEXES

\begin{tabular}{cccc}
\hline Sample code & $\mathrm{IPa}^{\mathrm{e}-6}$ & $\mathrm{IPc}^{\mathrm{e}-6}$ & $\mathrm{IPa} / \mathrm{IPc}$ \\
\hline \multirow{2}{*}{ C6P1 } & 2.501 & 4.669 & 0.535 \\
& 4.499 & 5.669 & 0.794 \\
\hline \multirow{2}{*}{ C6P2 } & 1.808 & 2.100 & 0.861 \\
& 3.564 & 5.872 & 0.607 \\
\hline \multirow{2}{*}{ C6P3 } & 1.716 & 2.007 & 0.855 \\
& 1.675 & 2.582 & 0.649 \\
\hline
\end{tabular}




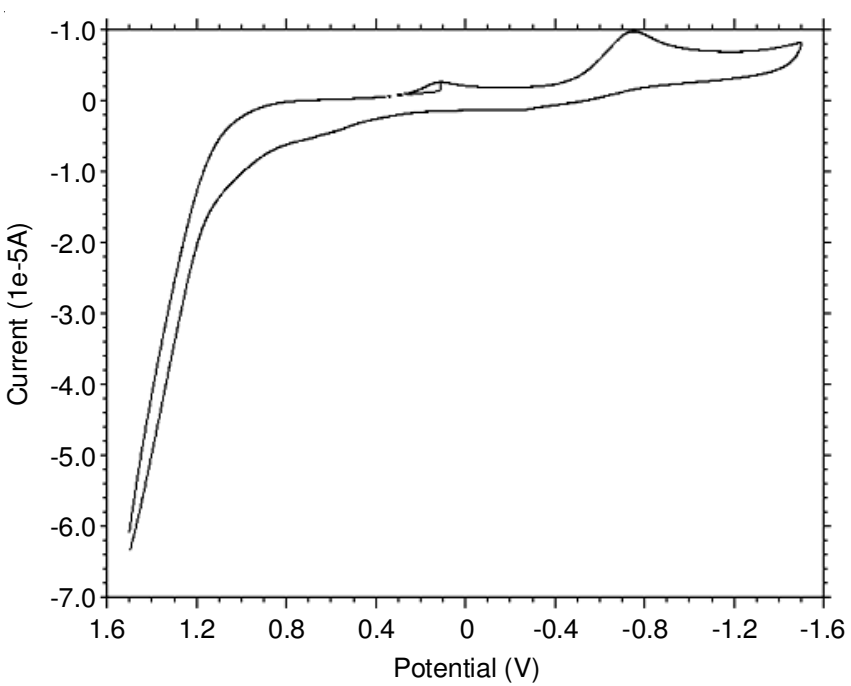

Fig. 8. Cyclic voltammetry of complex C6P1

\begin{tabular}{ccccc} 
TABLE-5 \\
CYTOTOXIC ACTIVITY OF LIGAND AND COMPLEXS \\
\hline $\begin{array}{c}\text { Drug concentration } \\
(\mu \mathrm{g} / \mathrm{mL})\end{array}$ & L6 & C6rcent cell death for EAC \\
\hline 200 & 30 & 72 & C6P2 & C6P3 \\
\hline 100 & 17 & 60 & 56 & 75 \\
50 & 10 & 52 & 49 & 40 \\
20 & 0 & 38 & 32 & 36 \\
10 & 0 & 20 & 18 & 25 \\
\hline
\end{tabular}

ligand molecule. In drug concentration $200 \mu \mathrm{g}$, about $75 \%$ of the tumor cells were killed by the complexes.

\section{Conclusion}

A multidentate ligand was synthesized by using 4-t-butyl2,6-bis-(chloromethyl) phenol and isonicotinic hydrazide. It was characterized by UV-visible, FT-IR, ${ }^{1} \mathrm{H}$ NMR, ${ }^{13} \mathrm{C}$ NMR spectral studies. The above ligand was coordinated with various copper precursors to form corresponding copper complexes. The complexes were characterized by UV-visible, FT-IR, conductivity measurements and cyclic voltammetry. The molar conductance values show that all the complexes are found to be 1:2 electrolyte. In vitro cytotoxicity study shows that all the complexes were showing activity against Ehrlich ascites carcinoma cell.

\section{ACKNOWLEDGEMENTS}

The authors thank Thiruvalluvar University, Muthurangam Government Arts College and Amala Cancer Research Institute for providing the necessary help during the course of work.

\section{REFERENCES}

1. R.A. Friesner, M.-H. Baik, B.F. Gherman, V. Guallar, M. Wirstam and R.B. Murphy, Coord. Chem. Rev., 238-239, 267 (2003); https://doi.org/10.1016/S0010-8545(02)00284-9.
2. A. Decker and E.I. Solomon, Curr. Opin. Chem. Biol., 9, 152 (2005); https://doi.org/10.1016/j.cbpa.2005.02.012.

3. E.A. Lewis and W.B. Tolman, Chem. Rev., 104, 1047 (2004); https://doi.org/10.1021/cr020633r.

4. C.J. Grimes, D. Piszkiewicz and E.B. Fleischer, Proc. Natl. Acad. Sci. USA, 71, 1408 (1974); https://doi.org/10.1073/pnas.71.4.1408.

5. C. Culotta, M. Yang and T.V. O'Halloran, Biochim. Biophys. Acta, 1763, 747 (2006); https://doi.org/10.1016/j.bbamcr.2006.05.003.

6. C. Marzano, M. Pellei, F. Tisato and C. Santini, Anticancer. Agents Med. Chem., 9, 185 (2009);

https://doi.org/10.2174/187152009787313837.

7. R. Tabti, N. Tounsi, C. Gaiddon, E. Bentouhami and L. Désaubry, Med. Sci., 7, 875 (2017); https://doi.org/10.4172/2161-0444.1000445.

8. I. Warad, A.F. Eftaiha, M.A. Al-Nuri, A.I. Husein, M. Assal, A. Abu-Obaid, N. Al-Zaqri, T.B. Hadda and B. Hammouti, Mater. Environ. Sci., 4, 542 (2013).

9. G. Ambrosi, M. Formica, V. Fusi, L. Giorgi and M. Micheloni, Coord. Chem. Rev., 252, 1121 (2008); https://doi.org/10.1016/j.ccr.2007.09.027.

10. R.J. Nahi and K.M. Hello, Al-Qadisiya J. Vet. Med. Sci., 7, 1 (2008)

11. M. Ashram, J. Incl. Phenom. Macrocycl. Chem., 54, 253 (2006); https://doi.org/10.1007/s10847-005-8648-y.

12. L.J. Daumann, K.E. Dalle, G. Schenk, R.P. McGeary, P.V. Bernhardt, D.L. Ollis and L.R. Gahan, Dalton Trans., 41, 1695 (2012); https://doi.org/10.1039/C1DT11187F.

13. J. Medvecká, J. Halaska, K. Jomova and J. Moncol, Acta Chim. Slovaca, 5, 15 (2012); https://doi.org/10.2478/v10188-012-0003-5.

14. S.J. Jenniefer and P.T. Muthiah, Chem. Cent. J., 7, 35 (2013); https://doi.org/10.1186/1752-153X-7-35.

15. M. Iqbal, S. Ali, N. Muhammad and M. Sohail, Polyhedron, 57, 83 (2013); https://doi.org/10.1016/j.poly.2013.04.020.

16. M. Iqbal, I. Ahmad, S. Ali, N. Muhammad, S. Ahmed and M. Sohail, Polyhedron, 50, 524 (2013); https://doi.org/10.1016/j.poly.2012.11.037.

17. G. Negrón-Silva, R. González-Olvera, D. Angeles-Beltrán, N. Maldonado-Carmona, A. Espinoza-Vázquez, M. Palomar-Pardavé, M. Romero-Romo and R. Santillan, Molecules, 18, 4613 (2013); https://doi.org/10.3390/molecules 18044613.

18. L.H. Abdel-Rahman, A.M. Abu-Dief, S.K. Hamdan and A.A. Seleem, Int. J. Nanomater. Chem., 1, 65 (2015); https://doi.org/10.12785/ijnc/010204.

19. D. Menon K, S. Dharmapal, C.R. Achuthan and T.D. Babu, J. Pharmacogn. Phytochem., 3, 1 (2014).

20. P.V. Mahadimane and V. Vasudev, Int. J. Life Sci. Pharma Res., 3, L22 (2013).

21. M. Ozaslan, I.D. Karagoz, I.H. Kilic and M.E. Guldur, Afr. J. Biotechnol., 10, 2375 (2011).

22. A.F. Abd El-Aziz, M.E. Hefni and A.M. Shalaby, Int. J.Curr. Res. Acad. Rev., 2, 330 (2014).

23. L. Giri and V.R. Pedireddi, J. Mol. Struct., 1100, 455 (2015); https://doi.org/10.1016/j.molstruc.2015.07.064.

24. E. Pahontu, D.-C. Ilies, S. Shova, C. Paraschivescu, M. Badea, A. Gulea and T. Rosu, Molecules, 20, 5771 (2015); https://doi.org/10.3390/molecules20045771.

25. L.F. Marques, M.V. Marinho, C.C. Correa, N.L. Speziali, R. Diniz and F.C. Machado, Inorg. Chim. Acta, 368, 242 (2011); https://doi.org/10.1016/j.ica.2010.12.055. 